\title{
Erratum: Adaptation of a simple dipstick test for detection of Vibrio cholerae 01 and 0139 in environmental water
}

\author{
Subhra Chakraborty ${ }^{1}$, Munirul Alam ${ }^{2}$, Heather M. Scobie ${ }^{1}$ and David A. Sack ${ }^{1 *}$ \\ ${ }^{1}$ Department of International Health, Johns Hopkins Bloomberg School of Public Health, Baltimore, MD, USA \\ ${ }^{2}$ Centre for Communicable Diseases, International Centre for Diarrhoeal Disease Research, Dhaka, Bangladesh \\ ${ }^{*}$ Correspondence: dsack@jhsph.edu \\ Edited by: \\ Daniela Ceccarelli, University of Maryland, USA
}

Keywords: cholera, dipstick, Bangladesh, environmental water, Vibrio cholerae

\section{An erratum on:}

Adaptation of a simple dipstick test for detection of Vibrio cholerae $\mathrm{O} 1$ and $\mathrm{O} 139$ in environmental water

by Chakraborty, S., Alam, M., Scobie, H. M., and Sack, D. A. (2013). Front. Microbiol. 4:320. doi: 10.3389/fmicb.2013.00320

Two references cited in this article were incorrect. The reference to Ingram et al. (1996) should instead be Page et al. (2012) and the reference for Rabbani et al. (2001) should instead be Ley et al. (2012).

\section{REFERENCES}

Ley, B., Khatib, A. M., Thriemer, K., von Seidlein, L., Deen, J., Mukhopadyay, A., et al. (2012). Evaluation of a rapid dipstick (crystal VC) for the diagnosis of cholera in Zanzibar and a comparison with previous studies. PLoS ONE 7:e36930. doi: 10.1371/journal.pone.0036930

Page, A. L., Alberti, K. P., Mondonge, V., Rauzier, J., Quilici, M. L., and Guerin, P. J. (2012). Evaluation of a rapid test for the diagnosis of cholera in the absence of a gold standard. PLoS ONE 7:e37360. doi: 10.1371/journal.pone.00 37360

Received: 06 December 2013; accepted: 06 December 2013; published online: 24 December 2013.
Citation: Chakraborty S, Alam M, Scobie HM and Sack DA (2013) Erratum: Adaptation of a simple dipstick test for detection of Vibrio cholerae O1 and O139 in environmental water. Front. Microbiol. 4:405. doi: 10.3389/ fmicb.2013.00405

This article was submitted to Aquatic Microbiology, a section of the journal Frontiers in Microbiology.

Copyright (c) 2013 Chakraborty, Alam, Scobie and Sack. This is an open-access article distributed under the terms of the Creative Commons Attribution License (CC BY). The use, distribution or reproduction in other forums is permitted, provided the original author(s) or licensor are credited and that the original publication in this journal is cited, in accordance with accepted academic practice. No use, distribution or reproduction is permitted which does not comply with these terms. 